\title{
Methods of Selection and Acquisition of European French Monographs in an Academic Law Library
}

\author{
SVETLANA KOCHKINA \\ McGill University, Montreal, Canada
}

\begin{abstract}
This article examines methods of selection and acquisition for European (as opposed to Canadian) French-language print monographs for a research-level law library collection in North America based on the study of the practices and techniques locally developed in the Nabum Gelber Law Library, McGill University. These techniques represent a combination of non-approval plan-based methods: blanketorder, standing orders, online slip service in WorldCat, use of other libraries' acquisition lists, and firm orders. The methods described in this article are not exclusive to the selection in the subject area of law and could be applied in other academic disciplines.
\end{abstract}

KEYWORDS selection, acquisition, collection development, French monographs, foreign materials, law libraries, non-approval plan-based (NAPB) methods

\section{INTRODUCTION AND LITERATURE REVIEW}

Selection and acquisition of foreign materials for research-level collections of North American academic libraries is a challenging task that has been a subject of recurrent interest for the North American library community over the years. In a major effort to address the issue of acquisition and distribution of foreign language and area studies materials, a special task force was initiated by the Association of American Universities (AAU) in collaboration with the Association of Research Libraries (ARL). This initiative culminated in a report outlining a network-based, distributed program for the coordinated development of foreign acquisitions for U.S. and Canadian

Address correspondence to Svetlana Kochkina, Nahum Gelber Law Library, McGill University, 3660 Peel Street, Montreal, QC H3A 1W9, Canada. E-mail: svetlana.kochkina@mcgill.ca 
research libraries as a solution for improving access to international research and scholarly resources ("Acquisition and Distribution of Foreign Language and Area Studies Materials" 2000). The issue of cooperative acquisitions of foreign language materials specific to the subject field of law, has been repeatedly discussed (Butler 2001; Kimbrough 2007; Fitchett et al. 2011), with the conclusion that with few exceptions, this type of acquisition has been unsuccessful due to funding and staffing issues, significant differences in law school curricula and faculty research interests, and variance in emphasis on research versus professional training.

However, until recently, there has been a registered lack of scholarly or professional literature describing selection and acquisition methods as well as providing practical advice and guidance for librarians responsible for foreign language collection development. For example, Astroff has recorded a "startling absence of suggestions" (2001, 12) of collection development techniques for selectors in foreign languages. In her article, Astroff (2001) suggests a variety of tools that can be used by Spanish-language selectors. Later, this insufficiency was acknowledged in an indirect way in the review articles by Dunham and Davis (2009), Bullis and Smith (2011), and Harrell (2012). Those three extensive reviews of professional and scholarly literature on the subject of acquisition and collection development mention only two articles that provide models and techniques for the acquisition of foreign language materials: the papers by Dali and Dilevko (2005) and Ward (2009). The study by Dali and Dilevko (2005) on the collecting and acquisition processes used by the Slavic selectors in North American libraries provides insight into selection techniques and methods that can be helpful for librarians selecting not only in Slavic and East European but also in other foreign languages. Ward (2009) presents an excellent analysis of the methods of acquisition of foreign language materials used at a large academic library and offers a model of acquisition that could be applied at other research libraries selecting and acquiring this challenging material. The papers by Dali and Dilevko and Ward have successfully begun to fill in the lacuna in scholarly and professional literature on modern methods of acquisition of foreign language materials.

Nonetheless, one important area of foreign language acquisition is still lacking attention: techniques and tools for selection and acquisition of print French-language publications for research-level collections of North American academic libraries. The most recent article specifically discussing the subject of selection and acquisition methods for print French monographs was published in 1980 (Coscarelli and Chalaron). Since that time, professional practices in the field has changed dramatically. Two later articles (Benaud and Bordeianu 1997; Briscoe 1999), which have provided a survey of North American vendors for Francophone materials and a historical overview of French international booksellers, respectively, are exceedingly informative on the subjects of vendors, their services, and the history of this segment of 
the booksellers' market. However, they did not fill the existing gap with regard to the selection and acquisition methods for their products. More recent information on the services offered by vendors and several useful insights on the selection and acquisition of European French language publications have been presented in the literature review paper by Ward (2009) cited above. Still, no up-to-date article covers a broad variety of selection and acquisition tools, techniques, and workflows that have to be used in order for an academic library to build the strongest possible research level collection of European French-language materials on a specific subject. The present paper aims to fill this gap by examining local collection development practices for the selection and acquisition of print European (as opposed to Canadian) French-language monographs used at the Nahum Gelber Law Library (Law Library hereafter), a branch of the McGill University Library. The methods described in the paper are not exclusive to the selection in the subject area of law and could be applied to the selection and acquisition of French materials for other academic disciplines.

\section{THE LAW LIBRARY COLLECTION IN CONTEXT}

Because the main raison d'être of academic law libraries is to support faculty research and the curriculum of the affiliated law school, an academic law library must develop its collections to accomplish this goal (Lewis 2002; Lenz 2004). The chief mandate of the Law Library is to support a bilingual (English and French) transsystemic program of the McGill Law School, where students obtain a double degree of civil law and common law and where civil law and common law are taught in the same courses in a noncomparative manner. ${ }^{1}$ The roots of the transsystemic model of legal education lie in the bijural nature of the Quebec legal system, where the Quebec private law, derived from the French civil law tradition, coexists with the public law of Canada, which has its origins in the English common law tradition. The bilingual nature of the law program is due to the geographical situation of the McGill Law School. Anglophone McGill University is located in bilingual Montreal, the largest city in the Francophone province of Quebec, which is an integral part of English-speaking Canada. Because of this bilingual and bijural position, McGill University Law School has offered a bijural legal education since 1968, when the National Program ${ }^{2}$ was established, which allowed students to obtain civil law and common law degrees consecutively over the course of four years. However, the National Program in all its three iterations was never "a fully bilingual and intellectually integrated, polyjural four-year tuition rooted in a universalist model of legal education" (Macdonald 1990, 313). To achieve the goal of teaching the law as a discipline not confined to a specific jurisdiction or a legal tradition, the McGill University Law School implemented the transsystemic legal education program in 1999. 
Under the transsystemic program, the legal traditions are studied in an integrated pluralistic way that invites "students and scholars to think of law in a new way, in terms others than those of jurisdictional or geographical representations of law [...]" (Kasirer 2002, 31). The transsystemic program "provides this opportunity to teach in Law's cosmos rather than in Law's empire" (Kasirer, 31).

The complex and challenging mandate to support teaching, learning, and research activities of the law school offering a transsystemic program has profoundly influenced the collection development policies and practices of the Law Library. It created the need for the full and equal bibliographic support of the program studying both major legal traditions, common law and civil law, in both French and English. When the transsystemic program was created, the Law Library had to "fill huge gaps in the collection" (Côté 2013, 334). The initial emphasis was on "enhancing the depth of resources form civil law jurisdictions outside the province of Quebec from a minimal level to a research level while maintaining a strong common law collection" (Côté, 331). At present, a full range of materials on common law and civil law is acquired, with a special emphasis placed on the acquisition of materials on comparative and international law. Due to the bilingual nature of the program and to the unique linguistic identity of the province of Quebec, the French-language materials are not collected as "foreign materials" at the Law Library. On the contrary, both English and French are considered primary languages of the collection.

One of the most radical changes in the collection development policy of the Law Library, implemented after the institution of the transsystemic program and with the unfailing support of the law school's faculty, has been a fivefold increase of the budget devoted to the acquisition of monographic materials of a scholarly interest. Due to this increase, which allows the full and equal bibliographic support of two legal traditions in both languages, the Law Library currently devotes half of its budget to the purchase of researchlevel print monographs. Such budget allocation enables the Law Library to respond better to the research and teaching needs of the faculty and to provide access to doctrinal (secondary) sources published in monographic format that would be unaffordable otherwise. The budget reallocation was made possible by acquiring serials, case reporters, codes, and law reviews, if available, only in electronic format and eschewing acquisition of looseleaf materials and legal materials of an exclusively practical nature (McGill University Library 2012). The budget reallocation was followed by the implementation of complex selection practices and acquisition methods for print French-language monographs, which are described in the subsequent section of the present paper.

An analysis of the law subject subdivision of the McGill University Library collection was performed with the WorldCat Collection Analysis tool to investigate how the changes in the collection development policy and 
acquisitions practices have influenced the volume of acquisition of the monographic materials. The WorldCat Collection Analysis tool permits one to analyze the whole collation of a participating institution but not a part of the collection located in a specific branch. In the analysis, the collection is subdivided by subject but not by location (branch library). Because all of McGill University Library's materials pertaining to the law subject subdivision are housed at the Law Library, the analysis of the law subject subdivision accurately evaluates the collection of the Law Library. The WorldCat Collection Analysis tool does not use the acquisition dates of the analyzed materials. The analysis is performed based on the dates of publication. However, these data can be regarded as an accurate representation of the changes in the acquisition and selection practices of the Law Library for two reasons. First, because legal information becomes quickly outdated, the Law Library's collection development practices require that any recently published materials are made available to the users during the year of publication, or at the very latest, during the subsequent year. Second, for the last 20 years, there has been no special retrospective acquisition project implemented at the Law Library. Therefore, the date of publication can be regarded as a valid indicator of the period of acquisition of the material and can be used to determine and describe the trends in collection development.

The analysis of the law subject subdivision demonstrates that the average annual acquisition of print monographic materials increased 2.45 times for English-language monographs, 2.79 times for French-language monographs, and 3.97 times for French-language monographs for the subject group Law of Europe except UK and Ireland (See Table 1) between 1999 and 2010. 1999 was the year of implementation of the transsystemic model of legal education and of the subsequent changes in the collection development practices. The most significant increase is registered for the French monographic materials representing the subject group Law of Europe except UK and Ireland.

With regard to the acquisition of French monographic materials for the support of legal education in North America, special mention should be made on the subject of the acquisition of e-books, even though they are not the focus of the present article. As stated by Palfrey, the modern "law library $[. .$.$] is not entirely digital. Nor in all likelihood, will the law library$ ever be entirely digital" because many current monographs in law still exist

TABLE 1 Acquisition of Print Monographs: Average per Year

\begin{tabular}{lccc}
\hline Period & $\begin{array}{c}\text { English- } \\
\text { Language } \\
\text { Monographs }\end{array}$ & $\begin{array}{c}\text { French-Language } \\
\text { Monographs }\end{array}$ & $\begin{array}{c}\text { French-Language } \\
\text { Monographs, Law of } \\
\text { Europe }\end{array}$ \\
\hline 1990-1999 & 736.5 & 218.8 & 97.6 \\
2000-2010 & $1,802.0$ & 610.8 & 387.6 \\
Increase (number of times) & 2.45 & 2.79 & 3.97 \\
\hline
\end{tabular}


only in print version (2010, 175). This is especially true for the European French-language monographs. The acquisition of print European Frenchlanguage monographs cannot be expected to be replaced by the purchasing of electronic books in the foreseeable future as opposed, possibly, to their English counterparts or electronic journals, because of the extremely limited availability of scholarly and research-level French publications in the e-book format. As of October 2012, Dalloz is the only major French legal publishing house offering a subscription-based e-book platform. All other French legal publishers offer e-books as stand-alone downloadable .pdf files (sometimes complimentary to the print publication), for example, the e-books published by Hartmann. These files are meant for personal use with no institutional licensing available and have to be downloaded and hosted on a personal device. Thus, even in the case when and if those e-books can be legally lent to library users, they have to be hosted on a local server and accessed through a homemade platform, a labor-intensive and staff-intensive endeavor, which makes the acquisition of print monographs the most cost- and timeeffective choice for French-language selectors in North American academic libraries.

\section{METHODS OF SELECTION AND ACQUISITION}

It has been stated by Astroff (2001), Dali and Dilevko (2005), and Ward (2009) that the language proficiency of a selector and acquisitions staff above a bibliographic level is the first necessary condition to make library's collection development efforts in a foreign language successful. In the case of selection and acquisition of European French-language titles for the Law Library collection, this condition is met by the French-language selector and acquisition department staff members, most of whom are either fluently bilingual or have at least an advanced level of French language skills. Just a proficiency in French is not sufficient for building a strong research-level monographic collection when methods of selection and acquisition that significantly differ from English-language acquisition practices. The study of the Law Library collection development practices confirms the findings by Ward that "in comparison to English language acquisitions, the workflow to acquire foreign language titles is typically characterized by less automation, longer processing times, and more frequent human intervention" (2009, 91). In fact, as the example of the Law Library demonstrates, the effectiveness of collection development efforts for French-language monographs directly depends on the judicious mixture of automated and nonautomated selection and acquisition methods and especially on the intensive use of non-approval plan-based (NAPB) methods. Unlike English materials and similar to Slavic and East European materials (Dali and Dilevko 2005), the selection and acquisition of European French monographs outside of approval plans, through NAPB 
TABLE 2 Print French-Language Monographs: Distribution of Acquisitions by NAPB Method in 2011

\begin{tabular}{|c|c|c|c|c|}
\hline & Blanket Orders & Standing Orders & WorldCat Selection & Firm Orders \\
\hline Number of Titles & 115 & 74 & 251 & 631 \\
\hline$\%$ of Total Acquired & $11 \%$ & $7 \%$ & $23 \%$ & $59 \%$ \\
\hline
\end{tabular}

methods, remains an essential method of collection development, in particular for libraries that desire to develop a research-level French-language collection.

Due to the limited availability of European French-language monographs in North America, it is not feasible to set up a comprehensive approval plan for an academic library that develops a research-level French collection, particularly when French is not a foreign language but one of the two primary languages of education. Thus, the Law Library does not have an approval plan for these materials but instead uses a variety of the NAPB methods that have to be put in place to allow the development of a balanced and comprehensive research-level collection. At the Law Library, French-language monographs are selected and acquired through a range of following NAPB methods (see Table 2 for distribution of the acquisitions in 2011 by NAPB method):

- Blanket order

- Range of standing orders on monographic series and individual titles

- Firm orders for which the materials are selected from:

- Lists of books/book reviews published in book review magazines and book review databases

- Lists of new acquisitions by other institutions

- Publishers' promotional materials (catalogues, flyers, newsletters, etc.)

- Vendors' newsletters

- Publishers' and bookstores' Web sites

- Vendor's online slip service offered through WorldCat Selection Services

Each method of selection and acquisition has its rationale and justification for use as well as its limitations, which are discussed below.

"Under a typical blanket plan, a library receives comprehensive coverage of all titles published by particular presses or all titles published in specified subject areas" (Fenner 2004, 228). The Law Library's blanket order covers French-language monographs published in the subject category "law" by the Belgian publisher Brulyant and is placed with the Canadian vendor, Diffusion et Promotion du Livre Universitaire (DPLU)/University Books Sales and Services (UBSS). (See the Appendix for the description of selection and acquisition sources.) 
Standing orders are, as a rule, a simple and reliable acquisition method for French monographic series (e.g., Nouvelle Bibliothèque de Thèses) or, for French individual titles, issued either in several parts over a period of time or regularly published in a new edition (e.g., Droit Civil: Les Obligations) published by Dalloz. The advantages of this acquisition method are obvious: Through a standing order, publishers and vendors automatically supply each volume, edition, or part of a series as published until further notice, which allows the French selector and the acquisition department staff to save time on the purchase of monographs and avoid having incomplete multivolume series and sets or missing a new edition of an important work. However, standing orders are not entirely problem-free. The most common issues encountered while receiving European French-language monographs through standing orders, include omission by publisher or vendor of a new edition or part of the series; untimely shipment of the publications; and failure to notify the library about a change of the publisher, series, title, or authorship of a monograph that may lead to a lengthy nonreceipt of the publication or total cancellation of a standing order. One solution, developed at the Law Library, is a yearly verification of standing orders for completeness with subsequent claiming of the missed publications. This allows staff to catch omitted editions and parts. However, because this solution is labor-intensive and time-consuming, it is recommended only for a reasonably limited and manageable number of titles.

The main source of European French-language monographs at the Law Library is firm orders, which account for $59 \%$ of the total number of acquisitions of this type of material (see Table 2). For firm orders, the monographs are selected from a large array of sources. The most important of those sources is a list of new books published in France and new books published in French in Belgium and Switzerland found in the magazine Livres de France. Livres de France is a monthly aggregation of weekly lists printed in Livres Hebdo (ISSN 0294-0000). In Livres de France, the list of new publications is conveniently subdivided by subject categories that correspond broadly to the Dewey classes and subclasses and range from "administration publique" (public administration) to "mathematiques" (mathematics) and "urbanism." Short, informative reviews are available for all publications as well as ISBNs, publisher information, pagination, etc. The French selectors at the Law Library traditionally use the print edition of Livres de France and find it to be the most efficient tool to keep abreast of and to select new French publications. Recently, Cercle de la Librairie, the publisher of Livres de France, launched an online database of French publications, Electre, with its North American adapted version, Memento, and the current French selector has begun using this database in conjunction with the print edition of Livres de France. However, a comparison of the titles, grouped under the subject "droit" (law) in the Livres de France and in Memento under "droit et justice" (law and justice) for a given month, revealed that the content of 
those categories is not identical. A large number of publications pertaining rather to the subject of political science than to law are included in the category "droit et justice" (law and justice) in the Memento as compared to the "droit" (law) in Livres de France. This broader treatment of subject divisions makes the selection work more time-consuming without adding significantly more titles to the final selection. As a consequence, the print edition of Livres de France is still used as the primary selection source for firm orders.

The second most important selection source for firm orders for European French-language monographs is the recent acquisitions lists of the Library of Swiss Institute of Comparative Law. These highly informative lists, posted periodically on the library Web site as .pdf files, have proved to be an essential selection tool because they include a large number of hard-to-find publications issued by small presses and Festschrifts. Festschrifts, collections of thematic essays honoring renowned scholars in the field, are sometimes printed in limited runs and often omitted from the lists of new publications published in journals and magazines, rendering them "difficult" to collect exhaustively as is required by the Law Collection Policy (McGill University Library 2012). This makes the lists of recent acquisitions by the Library of Swiss Institute of Comparative Law an indispensable selection tool for collecting French-language Festschrifts published in Europe. In addition to the selection sources for firm orders listed above, the Law Library's French selector uses a variety of other sources, such as publishers' catalogues (e.g., of the Belgian publishing house Larcier), publishers' flyers, vendors' electronic newsletters (e.g., of DPLU/UBSS), and publishers' and bookstores' Web sites (e.g., of LGDJ or Decitre).

Finally, the Law Library French selector uses the online slip service offered through WorldCat Selection Services by the vendor Aux Amateurs de Livres. An online slip service has the advantages of electronic workflow because it decreases turnaround time from notification through selection, order, and cataloguing. In general, using the WorldCat Selection tool, as opposed to selection from paper-based sources, saves a selector's time because the tool displays information about the availability of a particular title in the selectors' library, allowing the selector to reject items already purchased. However, this method of selection and acquisition has two serious shortcomings. The first, not particular to the WorldCat Selection tool itself, depends on the availability of minimal-level cataloguing records that a vendor has loaded into WorldCat. Due to the limited demand for research-level European French-language monographs by North American law libraries, most of the slips offered through this service represent college-level or university undergraduate-level manuals, while fewer are for the research-level publications. Consequently, the online slip service is not sufficient for the collecting needs of the Law Library, hence the need for firm ordering as discussed earlier. 
The second shortcoming pertains to the WorldCat Selection tool itself. Items that have been ordered through other acquisition channels but not yet received, and for which only provisional records have been created in the Library Management System (LMS), are not shown in the WorldCat Selection tool as owned by the library, creating a danger of duplication. One possible method of overcoming this difficulty is to verify the availability of each publication in local LMS to determine whether there is a provisional record that has been created to indicate that the monograph has been already ordered. This process is time-consuming and undermines the some advantages of the WorldCat electronic slip selection service.

When a library receives print materials through a variety of acquisition sources, such as a blanket order, standing orders, firm orders, and an online slip selection service, the risk of duplication of new materials may be present to a great extent. In order to avoid duplication and also avoid checking each title ordered through the WorldCat Selection tool against existing provisional records in the LMS, several guidelines have been established at the Law Library. First, in order to not duplicate an existing blanket order, no title issued by the publisher Brulyant is ever ordered through any other acquisition channel. Second, standing orders are created only for publications for which missing a new edition is critical and not for all the monographs that are periodically published in a new edition. Keeping the number of standing orders to a minimum allows for quicker double-checking of a possible firm order against a list of series and titles received through standing orders. Third, McGill's vendor Aux Amateurs de Livres confirmed that it uses the list of new books published in Livres de France (Livres Hebdo) as the source of bibliographic data for creation of electronic slips that are sent to the selector by the end of the month. Therefore, to avoid ordering the same publications from WorldCat Selection tool and Livres de France, the following selection procedure is put in place. In a given month, the selection is first made in WorldCat Selection tool. Then, Acquisition Department staff create provisional records in the local LMS for the titles selected in the WorldCat Selection tool. After notification that all records for that batch are created, the French selector begins to choose the new monographs from the print issue of Livres de France, which contains the list of new books for the same month, thus avoiding duplication of orders for the titles included in both sources. Last, all firm orders for the Law Library are generally placed with the same vendor, Aux Amateurs de Livres, which also supplies publications ordered through the WorldCat Selection tool and diligently checks for duplicate orders. The combination of these measures allows the Law Library to avoid duplication even when such a complex selection and acquisition scheme is put in place.

Results of a comparison analysis of holdings over two decades, using the WorldCat Collection Analysis tool, indicate a considerable increase in the Law Library's acquisition of French-language monographs, affirming that 
TABLE 3 Unique Holdings in French-Language Monographs, Law of Europe

\begin{tabular}{lccc}
\hline \multirow{2}{*}{ Period } & $\begin{array}{c}\text { Number of } \\
\text { Unique Holdings }\end{array}$ & $\begin{array}{c}\% \text { of } \\
\text { Total Holdings }\end{array}$ & $\begin{array}{c}\text { \% of Unique } \\
\text { Holdings, Law Subject Group }\end{array}$ \\
\hline $1990-1999$ & 62 & $2.8 \%$ & $39 \%$ \\
$2000-2010$ & 503 & $7.4 \%$ & $78.7 \%$ \\
\hline
\end{tabular}

the methods and procedures for collecting these materials are effective. The proportion of unique French-language monographs for the subject subdivision Law of Europe except UK and Ireland as compared to all of WorldCat libraries increased considerably in 2000 through 2010 in comparison to 1990 through 1999 (see Table 3).

The increase was registered not only in the number of unique holdings compared to the number of total holdings but also when evaluated against unique holdings on the broad "law" subject group. In 1990 through 1999, only 39\% of unique holdings in French monographs accounted for the subject group "law of Europe," while this proportion increased to $78.7 \%$ in 2000 through 2010. This increase demonstrates the effect of the changes in collection development practices that followed the implementation of the transsystemic model of legal education and of the application of the selection and acquisition scheme described above.

\section{CONCLUSION}

The experience of the Law Library clearly demonstrates that the acquisition of European French-language monographs at the research level for an academic library in North America is a time-consuming and challenging endeavor. This challenge, however, can be successfully overcome if the library is not relying on an approval plan for development of its European Frenchlanguage collection but is consistently and systematically using a variety of selection sources and acquisition methods.

According to the selection and acquisition experience of the Law Library, the use of the online slip service offered through the WorldCat Selection Services can be recommended for the libraries that aim to develop their French collection at the instructional level and do not collect extensively French research-level publications. WorldCat Selection electronic slips, used alone and not supplemented with the selection from other sources, allows one to completely avoid duplication without time-consuming double-checking; consequently, they can be recommended for the selectors who must balance their collection development duties for French materials with other position responsibilities. When a library's collection policy requires the development of the French collection at a research level, it is advisable to use other 
selection sources to supplement the WorldCat Selection electronic slips. According to the Law Library's experience, the best and the easiest-to-use selection source for French publications is the print book review magazine Livres de France. If for some reason a library cannot subscribe to Livres de France, the database Electre/Memento may be used for information about the recent publications in French. As discussed earlier, the Law Library prefers the print Livres de France over the electronic Electre/Memento database because of the overly broad treatment of the subject categories in the Electre/Memento, which makes the selection process longer and less efficient.

While Livres de France and Electre/Memento provide French selectors with a nearly comprehensive list of the recent publications in French published in France, they should be supplemented with other selection sources or other acquisition methods if a library is extensively collecting French publications from outside France and Canada. Firm orders based on information from Belgium or Swiss publishers' catalogues or blanket orders placed with a leading publisher for a given subject fill the gaps in the acquisition of French materials from these countries. Last, the North American vendors' newsletters or the new acquisition lists of other libraries can be recommended as selection sources that help to avoid missing interesting or important publications.

Selection and acquisition of foreign materials is an enchanting subject that still requires a lot of attention from the library community because traditional selection methods are not easily remedied by electronic selection tools and approval plans. The selection principles outlined in the present article, such as the use of various NAPB methods and of multiple selection sources, can be applied to the selection of French monographs for the academic discipline other than law or to collecting of other foreign language materials.

\section{ACKNOWLEDGMENTS}

I am profoundly grateful to my colleagues from McGill University Library, Megan Chellew and Louisa Piatti, for reading and commenting on the draft of this article.

\section{NOTES}

1. An extensive bibliography on transsystemic model of legal education can be found on the Web site of the Paul-André Crépeau Law Centre for Private and Comparative http://www.mcgill.ca/centrecrepeau/transsystemic/articles/.

2. For the detailed description and history of the National Program see Macdonald, R. A. "The National Law Programme at McGill: Origins, Establishment, Prospects.” 1990. Dalhousie Law Journal 13 (1): 211-363. 


\section{REFERENCES}

“Acquisition and Distribution of Foreign Language and Area Studies Materials." 2000. Journal of Library Administration 29 (3): 51-75.

Astroff, Roberta J. 2001. "Revitalizing a Foreign Literature Collection." Collection Building 20 (1): 11-7.

Benaud, C. L., and S. Bordeianu. 1997. "The Marketplace for French and Francophone Materials: A Survey of Vendors." Acquisitions and Collection Development in the Humanities 9 (17-18): 159-75.

Briscoe, Peter. 1999. "French International Booksellers, Suppliers to Libraries, à la Fin du Vingtiè me Siècle." Library Collections, Acquisitions, and Technical Services 23 (4): 401-10.

Bullis, Daryl R., and Lorre Smith. 2011. "Looking Back, Moving Forward in the Digital Age: A Review of the Collection Management and Development Literature, 2004-8." Library Resources \& Technical Services 55 (4): 205-20.

Butler, A. H. 2001. "Cooperative Collection Development Programs in Law Libraries: Barriers and Benefits." Legal Reference Services Quarterly 20 (3): 13-25.

Coscarelli, William F., and Peggy P. Chalaron. 1986. "Acquisition of French Language Monographic Materials." Collection Management 8 (1): 45-53.

Côté, Maryvon. 2013. "Building a Transsystemic Law Library Collection." In Library Collection Development for Professional Programs: Trends and Best Practices, edited by Sara Holder, 327-40. Hershey, PA: Information Science Reference.

Dali, Keren, and Juris Dilevko. 2005. "Beyond Approval Plans: Methods of Selection and Acquisition of Books in Slavic and East European Languages in North American Libraries." Library Collections, Acquisitions, and Technical Services 29 (3): 238-69.

Dunham, Barbara S., and Trisha L. Davis. 2009. "Literature of Acquisitions in Review, 2004-7.” Library Resources \& Technical Services 53 (4): 231-42.

Fenner, Audrey. 2004. "The Approval Plan." The Acquisitions Librarian 16 (31-32): 227-40.

Fitchett, T., J. Hambleton, P. Hazelton, and A. Klinefelter. 2011. "Law Library Budgets in Hard Times." Law Library Journal 103 (1): 91-111.

Harrell, Jeanne. 2012. "Literature of Acquisitions in Review, 2008-9." Library Resources \& Technical Services 56 (1): 4-13.

Kasirer, N. 2002. "Bijuralism in Law's Empire and in Law's Cosmos." Journal of Legal Education 52 (1-2): 29-41.

Kimbrough, T. 2007. "Building a Chinese Law Collection in the Academic Law Library." Legal Reference Services Quarterly 25 (4): 37-69.

Lenz, Connie. 2004. "Faculty Services in Academic Law Libraries: Emerging Role for the Collection Development Librarian." Law Library Journal 96 (2): 283-93.

Lewis, S. H. 2002. "Three-Tiered Approach to Faculty Services Librarianship in the Law School Environment." Law Library Journal 94 (1): 89-100.

Macdonald, R. A. 1990. "The National Law Programme at McGill: Origins, Establishment, Prospects." Dalhousie Law Journal 13 (1): 211-363.

McGill University Library. 2012. "Law collection policy." Accessed September 1, 2012. http://www.mcgill.ca/library/library-about/collection-policies/law/. 
Palfrey, J. 2010. "Cornerstones of Law Libraries for an Era of Digital-Plus." Law Library Journal 102 (2): 171-90.

Ward, Judith H. 2009. "Acquisitions Globalized: The Foreign Language Acquisitions Experience in a Research Library." Library Resources ow Technical Services 53 (2): 86-93.

\section{APPENDIX SELECTION AND ACQUISITION SOURCES}

1. Aux Amateurs de Livres http://www.auxam.fr/

Aux Amateurs de Livres was founded in the 1930s by Marcel Blancheteau. It initially specialized in the sale of rare and antiquarian books. In late 1930s, the company began to supply new books to major North American libraries. At present, Aux Amateurs de Livres sells monographs as well as other formats (DVDs, periodicals, etc.) through firm orders, standing orders, approval plans, and subscriptions. The company also offers outof-print books business and a database for online ordering. Since 1990s, Aux Amateurs de Livres supplies bibliographic records for French imprints to the OCLC.

2. Decitre http://www.decitre.fr/

Decitre is a French bookstore chain that began an online bookselling business in 1997. Its Web site is quite informative, with new publications added promptly and the book reviews available for most of the monographs.

3. Diffusion et Promotion du Livre Universitaire (DPLU)/University Books Sales and Services (UBSS) http://www.dplu.ca/

DPLU/UBSS, Montreal bookseller, specializes in the distribution of university publications of French publishers in North America. A newsletter and a listing of newly added titles are available. Book reviews are in French only.

4. Editions Bruylant http://www.bruylant.be/

Founded in 1838, Bruylant publishing house is one of two leading Belgian companies specializing in political science and law (Belgian law, international law, comparative law, European law, human rights, etc.). It publishes academic and practice-oriented monographs, periodicals, codes, and jurisprudence in French, Dutch, and English. In 2011, Bruylant joined publishing group De Boeck Group.

5. Editions Larcier http://editions.larcier.com/

Editions Larcier, a publishing house founded in 1839, is one of the two leading companies specializing in legal publishing in Belgium. Its main strength is publication of academic legal monographs, journals, monographic series, and collections of jurisprudence. It is well known for its high-quality series Codes Larcier. In 1991, Larcier joined publishing group De Boeck Group. 
6. Library of Swiss Institute of Comparative Law (recent acquisitions lists) http://www.isdc.ch/en/bibliotheque.asp/4-0-10508-5-4-0/4-010508-5-4-0/

Swiss Institute of Comparative Law specializes in research in the areas of national legal systems, international private and public law, and law of the European Union. The library of the institute collects extensively in these fields and posts lists of the latest acquisitions on its Web site.

7. Livres de France

Livres de France is a monthly aggregation of book reviews published in a weekly magazine, Livres Hebdo http://www.livreshebdo.fr/. Both Livres de France and Livres Hebdo are published by the Cercle de la Librairie. The list of new publications in Livres de France is subdivided by subject categories that correspond broadly to the Dewey classes and subclasses. Livres de France covers books published in all languages in France and offers a selective coverage of French language publications from Belgium and Switzerland.

8. LGDJ (Librairie Géné rale de Droit et de Jurisprudence) http://www.lgdj.fr/ LGDJ is one of the oldest French legal publishing houses, founded in 1836, which is now one of the brands of the publishing group Lextenso http://www.lextenso-editions.fr/. LGDJ continues a tradition of publishers/booksellers and owns a brick-and-mortar bookstore in Paris on rue Soufflot and an online bookstore. The latter is an excellent source of information for recent French publications in the areas of law, economics, finance, accounting, and management. One may subscribe to a newsletter, and book reviews are in French only.

9. Memento http://www.mementolivres.com/Search.aspx

Memento is a North American adapted version of the Electre http://electre.com. Electre is a database of forthcoming, in-print, and outof-print books published in all languages in France with selective coverage of French publications from Belgium and Switzerland. In addition to the content included in Electre, Memento covers books published in French in Quebec and the rest of Canada. Book reviews and complete bibliographic information are provided. There is a list of publishers and distributors with contact information and a feature for alerts for the new titles. 